\title{
The British Army, Information Management and the First World War Revolution in Military Affairs
}

\begin{abstract}
Information Management (IM) - the systematic ordering, processing and channelling of information within organisations - forms a critical component of modern military command and control systems. As a subject of scholarly enquiry, however, the history of military IM has been relatively poorly served. Employing new and under-utilised archival sources, this article takes the British Expeditionary Force (BEF) of the First World War as its case study and assesses the extent to which its IM system contributed to the emergence of the modern battlefield in 1918. It argues that the demands of fighting a modern war resulted in a general, but not universal, improvement in the BEF's IM techniques, which in turn laid the groundwork, albeit in embryonic form, for the IM systems of modern armies.
\end{abstract}

KEY WORDS: British Army, Information Management, First World War, Revolution in Military Affairs, Adaptation

In November 1915 the future novelist and playwright J.B. Priestley, then a lance-corporal, was sent to work as a temporary clerk on the operations staff of the British Expeditionary Force's (BEF's) III Corps. Summing up his two-week 'ordeal', Priestley felt he had been 'trapped in the middle of what seemed a huge idiotic system... committed to wasting men and time and money collecting and receiving and distributing and filing unnecessary information'. ${ }^{1}$ Echoing Priestley's sentiments, in a letter to his wife in January 1916 Cuthbert Headlam reflected upon the nature of his work as a General Staff Officer $3^{\text {rd }}$ Grade (GSO3) on the operations staff at Second Army headquarters:

[T]he work is purely clerical - so far as I am concerned up to now at any rate and not at all difficult if one were left to do it in one's own way and to make one's own decisions... But this is exactly what one is never allowed to do every silly little matter has to be looked at by half a dozen different officers and in the end it is so fingered and thumbed that one ceases to recognize it when

\footnotetext{
${ }^{1}$ J.B. Priestley, Margin Released: A Writer's Reminiscences and Reflections (London: Mercury Books, 1962), 104. For additional context, see Neil Hanson with Tom Priestley (eds.), Priestley's Wars (Ilkley: Great Northern Books, 2008).
} 
it is suddenly thrown back to one and asked where it came from. It is all dreadfully childish, old fashioned and bureaucratic.

Dissatisfied with being 'a glorified office boy', in March Headlam was transferred to Second Army's counter-espionage staff before being upgraded as a GSO2 and reassigned to the intelligence branch of VIII Corps in November. However, during his time there Headlam again wrote frequently about the disorder and inefficiency of office procedures, remarking that 'not one Staff Officer per cent out of those whom I have met has the vaguest idea about how an office ought to be run, or the remotest conception of what is meant by delegation of authority or division of labour'.2

Priestley and Headlam's experiences are intriguing, for they provide rare insights into the internal modus operandi of the BEF's command and control system, which itself has formed part of the enduring controversy surrounding British military operations during the First World War. William Philpott has provided a useful synthesis of the ongoing debate:

For several decades military historians in Britain have been re-examining myths and misperceptions about the British army's effectiveness on the battlefield... This historical revisionism began with the identification and consideration of the concept of a 'learning curve' of improving British military performance from the army's early and costly trench battles of 1915 and $1916 \ldots$ to the successful British advance and defeat of the German army in 1918. While the concept of a learning curve is now considered too simplistic, studying the process by which the British army adapted to modern industrialised warfare has been the predominant trend in Anglophone military history of the war since the 1990s...

\footnotetext{
${ }^{2}$ Letters to Beatrice, 13/14 January, 28 February, 17 November 1916; 7 February, 26 May 1917, in Jim Beach (ed.), The Military Papers of Lieutenant-Colonel Sir Cuthbert Headlam 1910-1942 (Stroud: History Press for the Army Records Society, 2010), 115, 117, 149, 156-7, 167.
} 
[T]he most recent tendency, which has yet to produce definite findings, has been to examine the processes of institutional learning and adaptation that allowed the army to rise to the challenges of modern war. ${ }^{3}$

Although scholarship has moved away from the rather stale debate on generalship and towards an examination of neglected military support functions such as logistics, intelligence and staff work, ${ }^{4}$ as well as investigating the BEF's methods for learning, ${ }^{5}$ there remains a significant gap in our understanding of one of the British army's most important command and control components, namely its communications and information system (CIS). ${ }^{6}$

While recent research has begun to correct this anomaly, ${ }^{7}$ discussions on communications invariably focus on how, and with what success, information was transmitted and received on the battlefield. ${ }^{8}$ To date, however, no historian has made a detailed attempt to consider what happened to this information both immediately before it was transmitted and once it reached its intended destination. This is a significant oversight, not only in light of the prodigious volume of information generated by the mass armies of the era, but also because today's armed forces recognise that information on its own is

\footnotetext{
${ }^{3}$ William Philpott, 'Military History a Century after the Great War', Revue Française de Civilisation Britannique [Online] 20/1 (2015), 2-3, < https://rfcb.revues.org/288 >.

${ }^{4}$ Ian Malcolm Brown, British Logistics on the Western Front 1914-1919 (Westport, CT.: Praeger, 1998); Jim Beach, Haig's Intelligence: GHQ and the German Army, 1916-1918 (Cambridge: Cambridge UP, 2013); Paul Harris, The Men Who Planned the War: A Study of the Staff of the British Army on the Western Front, 1914 1918 (London: Ashgate, 2016).

${ }^{5}$ Robert T. Foley, 'Dumb Donkeys or Cunning Foxes? Learning in the British and German Armies during the Great War', International Affairs 90/2 (2014), 279-98; Aimée Fox, Learning to Fight: Military Innovation and Change in the British Army, 1914-1918 (Cambridge: Cambridge UP, 2018).

${ }^{6}$ Defined as 'the assembly of equipment, methods and procedures, and if necessary personnel, organised so as to accomplish specific information, conveyance and processing functions'. JDP 6-00 (Third Edition), Communications and Information Systems Support to Joint Operations (January 2008), 1-1.

${ }^{7}$ Brian N. Hall, Communications and British Operations on the Western Front, 1914-1918 (Cambridge: Cambridge UP, 2017).

${ }^{8}$ R.E. Priestley, Work of the Royal Engineers in the European War, 1914-19: The Signal Service (France) (first published 1921; new ed., Uckfield: The Naval and Military Press Ltd., 2006); Bill Rawling, 'Communications in the Canadian Corps, 1915-1918: Wartime Technological Progress Revisited', Canadian Military History 3/2 (1994), 6-21; Mike Bullock and Laurence A. Lyons, Missed Signals on the Western Front: How the Slow Adoption of Wireless Restricted British Strategy and Operations in World War I (Jefferson, NC.: McFarland \& Company, 2010).
} 
meaningless unless they have efficient arrangements in place for ordering, processing and channelling it. ${ }^{9}$ According to current British military doctrine, the ability to accurately and rapidly convert information into knowledge, and then knowledge into action - what is referred to as information management (IM) - 'underpins the successful prosecution of military operations' by providing 'exploitable information on time, in the right place and format, to maximise freedom of action', enabling 'effective information exploitation and the achievement of situational awareness by commanders and staffs' ${ }^{10}$ Representing the point where command, staff work and signals converge, IM thus constitutes a critical function of modern military command and control systems. ${ }^{11}$

Indeed, since the early 1990s it has become fashionable to argue that unprecedented developments in digital communications and data processing technologies have led the armed forces of several Western states to undergo an information-based Revolution in Military Affairs (RMA). ${ }^{12}$ Although the RMA remains a much contested concept, ${ }^{13}$ historians have nonetheless attempted to identify past examples of RMAs and assess the extent that these RMAs depended on their information resources. ${ }^{14}$ So far, however, there has been no detailed exploration of military IM techniques during the First World War, ${ }^{15}$ the conflict which, according to some historians, witnessed the most important RMA to date: an

\footnotetext{
${ }^{9}$ Theo Farrell, 'The Dynamics of British Military Transformation', International Affairs 84/4 (2008), 777-807; Jim Storr, The Human Face of War (London: Continuum, 2009), 129-54.

10 JDP 6-00, Communications, 1-1. For the US perspective, see Joint Publication 6-0, Joint Communications System (June 2015), < http://www.dtic.mil/doctrine/new_pubs/jp6_0.pdf >.

${ }^{11}$ David S. Alberts and Richard E. Hayes, Understanding Command and Control (Washington: CCRP, 2006), 123-50. For a non-military perspective, see Matthew Hinton (ed.), Introducing Information Management: the Business Approach (Oxford: Butterworth-Heinemann, 2005).

${ }^{12}$ See, in particular, Journal of Strategic Studies 33/4 (2010), Special Issue: The Information Technology Revolution in Military Affairs.

${ }^{13}$ Jeffrey Collins and Andrew Futter (eds.), Reassessing the Revolution in Military Affairs: Transformation, Evolution and Lessons Learnt (London: Palgrave Macmillan, 2015), esp. 175-80.

${ }^{14}$ Emily O. Goldman (ed.), Information and Revolutions in Military Affairs (London: Routledge, 2005).

${ }^{15}$ Other organisations have been the subject of enquiry: Alistair Black and Rodney Brunt, 'Information Management in Business, Libraries and British Military Intelligence: Towards a History of Information Management', Journal of Documentation 55/4 (1999), 361-74.
} 
artillery-centred, combined-arms revolution, giving birth to 'the Modern Style of Warfare', ${ }^{16}$ whereby battles are 'synchronised and sequenced across space and time to form a coherent campaign which seeks, within the context of a wider strategy, to destroy the enemy's ability to resist by destroying his assets, his will to fight or his capacity to react' ${ }^{17}$

Using the BEF as a case study, therefore, this article has the opportunity to position the subject of IM within the wider context of the debates concerning the British army's learning processes and the First World War RMA, assessing the extent to which information resources contributed to the emergence of the modern battlefield in 1918. It is important to stress that this article draws a distinction between 'information' and 'intelligence'; the former 'refers to the location and activities of friendly troops', while the latter 'is the order of battle, dispositions and possible intentions of the enemy'. ${ }^{18}$ Within this context, the prewar British army Field Service Regulations identified five different forms that information on active operations could take: standing orders; routine orders; operation orders; messages; and reports. ${ }^{19}$ The analysis within this article will be directed predominantly towards the latter three, which deal with more time-sensitive and tactical/operational information, rather than the former two which are more administrative in nature. ${ }^{20}$

\footnotetext{
${ }^{16}$ Jonathan Bailey, 'The First World War and the Birth of Modern Warfare', in MacGregor Knox and Williamson Murray (eds.), The Dynamics of Military Revolution 1300-2050 (Cambridge: Cambridge UP, 2001), 132-53; Colin S. Gray, Strategy for Chaos: Revolutions in Military Affairs and the Evidence of History (London: Routledge, 2004), 170-221; Stephen Biddle, Military Power: Explaining Victory and Defeat in Modern Battle (Princeton: Princeton UP, 2004), 28-51.

${ }^{17}$ Jonathan Boff, Winning and Losing on the Western Front: The British Third Army and the Defeat of Germany in 1918 (Cambridge: Cambridge UP, 2012), 5.

${ }^{18}$ Dominick Graham and Shelford Bidwell, Coalitions, Politicians and Generals: Some Aspects of Command in Two World Wars (London: Brassey's, 1993), 29-30. For the BEF's intelligence processing methods, see Beach, Haig's Intelligence, 168-91.

${ }^{19}$ Field Service Regulations Part I: Operations (1909) (Reprinted, with Amendments, October 1914) (London: General Staff, War Office, 1914), 25-37.

${ }^{20}$ For an aspect of the administrative processing techniques of the army, see John Black, 'Behind the Scenes with the Pen and Ink Corps! The Role of the Army Pay Services during the Great War in Maintaining the Loyalty of the Fighting Soldier and Preserving the Social Fabric of the United Kingdom', War \& Society 35/3 (2016), 180-203.
} 
This article makes use of new and under-utilised British, Australian, Canadian and American archival sources in order to assess how, and to what extent, the BEF's IM system evolved during the course of the war. It begins by examining the state of IM within the British army at the turn of the twentieth century, comparing it with the wider developments that were occurring within the commercial and industrial sectors. It then examines the challenges that the war on the Western Front posed for the army's IM system, before assessing how well the system adapted to overcome them. The evidence presented here suggests that the demands of fighting a modern, industrialised war resulted in a general, but not universal, improvement in the BEF's IM techniques, which in turn laid the groundwork, be it in embryonic form, for the IM systems of modern armies.

\section{Pre-war Developments}

The British army's IM system upon the outbreak of war in 1914 was very much the product of the democratic and industrial revolutions of the nineteenth and early twentieth centuries, which had not only increased the size, firepower and mobility of military organisations but also brought about the bureaucratisation of command and control. ${ }^{21}$ This bureaucratisation was symptomatic of a wider trend that was occurring throughout Western society, the primary characteristics of which were the shift from personal to impersonal control; strict discipline, rules and procedures; the specialisation and division of labour; the development of managerial hierarchies; and the development of increasingly elaborate and intensive systems for collecting, storing and processing information. According to the German sociologist Max Weber, the chief cause of the growth of bureaucracy was the huge increase

\footnotetext{
${ }^{21}$ Christopher Dandeker, Surveillance, Power and Modernity (Cambridge: Polity Press, 1994), 82-90.
} 
in the size and complexity of the administrative tasks created by new communication and information technologies. ${ }^{22}$

The proliferation of commerce and the growth in the size of businesses and the number of workers they employed resulted in an ever-greater need for communication and a dramatic increase in the volume of information generated. This necessitated changes not only to the way businesses were managed but also the manner in which information was gathered, processed and disseminated. ${ }^{23}$ According to one historian, 'internal communication came to serve as a mechanism for managerial coordination and control of organizations'. The emphasis on informal oral communication gradually gave way to 'a complex and extensive formal communication system depending heavily on written documents of various sorts'. ${ }^{24}$ From the $1870 \mathrm{~s}$, American businesses experienced an information revolution in which new equipment and techniques 'transformed the office and the way firms dealt with information'. ${ }^{25}$ The introduction of new 'bureau technologies', such as typewriters, telephones and punched-card tabulating machines, combined with new techniques for handling information, such as pre-printed standard forms and vertical filing systems, enabled offices to process vast quantities of information more speedily and with greater efficiency. ${ }^{26}$ Yet the growth in the development and adoption of new office machinery in the US was not

\footnotetext{
22 James Beniger, The Control Revolution: Technological and Economic Origins of the Information Society (Cambridge, MA.: Harvard UP, 1986), 6-16. For an interesting take on how these new communication technologies and associated bureaucratic infrastructures created the 'technostate', which in turn facilitated enhanced modes of liberal governance, see Patrick Joyce, The State of Freedom: A Social History of the British State since 1800 (Cambridge: Cambridge UP, 2013).

${ }^{23}$ Youssef Cassis, Big Business: The European Experience in the Twentieth Century (Oxford: Oxford UP, 1997), 160-4; Edward Higgs, The Information State in England (London: Palgrave, 2004), 12.

${ }^{24}$ JoAnne Yates, Control through Communication: The Rise of System in American Management (Baltimore: John Hopkins UP, 1993), xv.

25 JoAnne Yates, 'Evolving Information Use in Firms, 1850-1920: Ideology and Information Techniques and Technologies', in Lisa Bud-Frierman (ed.), Information Acumen: The Understanding and Use of Knowledge in Modern Business (London: Routledge, 1994), 26.

${ }^{26}$ John Orbell, 'The Development of Office Technology', in Alison Turton (ed.), Managing Business Archives (London: Butterworth-Heinrmann, 1991), 60-83; Arthur L. Norberg, 'High Technology Calculation in the Early $20^{\text {th }}$ Century: Punched Card Machinery in Business and Government', Technology and Culture 31/4 (1990), 753-79.
} 
replicated to the same degree on the other side of the Atlantic. Although large-scale offices in Britain had developed much earlier than in the US, they became mechanised much later. ${ }^{27}$ Instead, IM in British business was defined by a specialisation of clerical function. ${ }^{28}$ The information systems of leading banks, insurance firms and rail companies relied principally upon hundreds of well-trained and experienced clerks, processing every transaction by hand, using steel nib and paper, with little help from new office machinery. ${ }^{29}$

Yet it was not just the commercial and industrial sectors that were affected by this IM revolution. As armies became larger and more complex, the more they too began to invest in the structures and techniques of the bureaucratic age. In conjunction with the railway, the employment of the electric telegraph helped facilitate the movement and control of ever larger armies over greater distances. ${ }^{30}$ Not only did the telegraph help to centralise command and control but, as an electronic means of 'real-time' communication, it brought with it a huge increase in the volume of correspondence. During the course of the Second Boer War (1899-1902), the British army transmitted over 13.5 million telegrams. ${ }^{31}$ Such a prodigious quantity of information necessitated an efficient system for processing and disseminating it, and the development of new organisations to undertake such tasks. The two most important in this regard were the General Staff and the Signal Service, established in 1906 and 1912,

\footnotetext{
${ }^{27}$ Alistair Black, Dave Muddiman and Helen Plant, The Early Information Society: Information Management in Britain before the Computer (Aldershot: Ashgate, 2007), 12-26.

${ }^{28}$ Martin Campbell-Kelly, 'Data Processing and Technological Change: The Post Office Savings Bank, 18611930', Technology and Culture 39/1 (1998), 1-32; idem, 'Information Technology and Organisational Change in the British Census, 1801-1911', in JoAnne Yates and John Van Maanen (eds.), Information Technology and Organizational Transformation: History, Rhetoric, and Practice (London: Sage, 2001), 35-58.

${ }^{29}$ Martin Campbell-Kelly, 'The Railway Clearing House and Victorian Data Processing', in Bud-Frierman (ed.), Information Acumen, 51-74.

${ }^{30}$ Martin van Creveld, Technology and War: From 2000 B.C. to the Present (New York: Free Press, 1989), $153-66$.

${ }^{31}$ Edward Spiers, The Late Victorian Army 1868-1902 (Manchester: Manchester UP, 1992), 322.
} 
respectively. ${ }^{32}$ Both, however, were late developments when compared to the US and German armies. ${ }^{33}$

Consequently, while part of the reason for Britain's supposed decline in economic predominance during this period derived from its outmoded form of business organisation, ${ }^{34}$ the patchy performance of the British army during the Boer War can also be attributed partly to its reluctance to accept the bureaucratic structures and administrative techniques required to wage modern warfare. ${ }^{35}$ Leopold Amery, war correspondent for The Times, for instance, noted that during the Battle of Spion Kop (23-24 January 1900):

Nobody... made any real, determined effort to transmit information or to discover what was happening... The systematic repetition of every message by several orderlies was not attempted, and, indeed, short as were the distances involved, messages by hand seem in many cases to have taken quite inordinate times to reach their destination. ${ }^{36}$

The defective transmission of information throughout the battle confirmed 'how inherently unreliable and subject to accidents' the British IM system was. ${ }^{37}$ These problems persisted during yearly manoeuvres after the war. In July 1905, one officer complained that the army's

\footnotetext{
32 David French and Brian Holden Reid (eds.), The British General Staff: Reform and Innovation, 1890-1939 (London: Routledge, 2002); Major-General R.F.H. Nalder, The Royal Corps of Signals: A History of its Antecedents and Development, 1800-1955 (London: Royal Signals Institution, 1958), 16-17.

${ }^{33}$ Rebecca Robbins Raines, Getting the Message Through: A Branch History of the US Army Signal Corps (Washington, D.C.: Centre of Military History, 1999), 3-8; Major Paul W. Evans, 'Strategic Signal Communication: A Study of Signal Communication as Applied to Large Field Forces, Based Upon the Operations of the German Signal Corps During the March on Paris in 1914', Signal Corps Bulletin 82 (1935), 24-58; Arden Bucholz, Moltke, Schlieffen and Prussian War Planning (Oxford: Berg, 1993).

${ }^{34}$ Stephen Broadberry and Sayantan Ghosal, 'From Counting House to the Modern Office: Explaining AngloAmerican Productivity Differences in Services, 1870-1990', Journal of Economic History 62/4 (2002), 967-98. For a contrasting perspective, see David Edgerton, Science, Technology and the British Industrial 'Decline', 1870-1970 (Cambridge: Cambridge UP, 1996).

${ }^{35}$ David French, The British Way in Warfare, 1688-2000 (London: Unwin Hyman, 1990), 155.

${ }^{36}$ L.S. Amery, The Times' History of the War in South Africa 1899-1902, Vol. III (London: Sampson Low, 1902), 298-301.

${ }^{37}$ Colonel Hubert du Cane (trans.), The War in South Africa: the Advance to Pretoria after Paardeberg, the Upper Tugela Campaign, etc. Prepared in the Historical Section of the Great General Staff, Berlin (London: John Murray, 1906), 169.
} 
system of correspondence was 'laborious and tedious', noting that the 'over-lapping' of office work, 'unnecessary waste of clerical labour' and 'cumbrous filing and registering procedures' had led to 'a loss of speed and efficiency' in processing information. ${ }^{38}$ These were flaws that could no longer be ignored. As the 1909 Field Service Regulations made clear: 'Timely information... is an essential factor of success in war'. Moreover:

The value of information depends to a great extent on the length of time that has elapsed since the events occurred to which it relates. It is of the first importance that information should be communicated with the least possible delay to the commanders for whose benefit it is intended... [T] he means of communication [should be] so organised as to ensure the rapid transmission of information. ${ }^{39}$

Thus, the army's IM system became the subject of much discussion in the years leading up to the First World War. The arrangements for handling incoming and outgoing correspondence within the General Headquarters (GHQ) General Staff (G) Branch, for example, were outlined formally in the 1912 Staff Manual (War). ${ }^{40}$ Separate from the Adjutant General's (A) Branch and the Quartermaster General's (Q) Branch, which dealt with administration and supply, respectively, G Branch was responsible for the planning and implementation of operations, the issuing of orders and the collection and dissemination of intelligence. ${ }^{41}$ It was divided into two sections: Operations $(\mathrm{O})$ and Intelligence (I). The Operations Section consisted of two sub-sections, $\mathrm{O}(\mathrm{a})$ and $\mathrm{O}(\mathrm{b}) . \mathrm{O}(\mathrm{a})$ was responsible for

\footnotetext{
${ }^{38}$ Captain H. Musgrave, 'The Army System of Correspondence', Royal Engineers Journal 2/1 (1905), 47-51.

${ }^{39}$ Field Service Regulations Part I, 119, 130.

${ }^{40}$ Staff Manual (War) (London: General Staff, War Office, 1912), WO32/4731, The National Archives (TNA), Kew.

${ }^{41}$ Field Service Regulations Part II: Organization and Administration (1909) (Reprinted, with Amendments, October 1914) (London: General Staff, War Office, 1914), 38-41. For additional context, see Dan Todman, 'The Grand Lamasery Revisited: General Headquarters on the Western Front, 1914-1918', in Gary Sheffield and Dan Todman (eds.), Command and Control on the Western Front: The British Army's Experience 1914-18 (Staplehurst: Spellmount, 2004), 39-70.
} 
planning operations, drafting plans and orders, and for intercommunication, while $\mathrm{O}(\mathrm{b})$ was charged with registering and filing all correspondence. From the details contained within the Staff Manual (War) and from the subsequent reports pertaining to the 1913 army exercises, an outline of the way in which information was channelled and processed through G Branch can be made (Figure 1).

As smooth as the mechanisms of $\mathrm{G}$ Branch appeared on paper, in practice, at both a test exercise at the Royal Military College in January 1913 and at army manoeuvres in the autumn, a number of flaws were revealed. Sir John French, who acted in the dual capacity as director and commander at the test exercise, complained that '[i]n a large and complicated organisation such as General Headquarters' there was a 'delay in important information reaching higher authorities, and of action being taken by subordinates'. He stressed that the work allotted to $\mathrm{O}(\mathrm{b})$ was particularly heavy. ${ }^{42}$ The autumn manoeuvres confirmed the problems experienced at the beginning of the year: the poor flow of information throughout the branch; the lack of coordination between the Operations and Intelligence Sections; an uncertainty as to how messages should be sent by the Signal Service; and, confusion about the registration and filing of correspondence. ${ }^{43}$ According to one staff captain, 'on average it took some 40-60 minutes to get operation orders typed, hectographed and ready for despatch'. ${ }^{44}$ Things were little better at another staff exercise which took place at Camberley in early 1914. Sir James Edmonds, the British official historian, alleges in his memoirs that Sir Henry Wilson's poor performance as Chief of Staff caused Sir William Robertson to whisper to Sir John French: 'If you go to war with that operations staff, you are as good as

\footnotetext{
42 'Report of a Conference of General Staff Officers at the Royal Military College, $13^{\text {th }}$ to $16^{\text {th }}$ January, 1913', 29, WO279/48, TNA.

43 'Notes by Lt-Col. Bird and Maj. Evans on the Working of Ob during the Army Exercise 1913', 3 October 1913, WO32/4731, 'Notes by O(b) General Headquarters. Brown Force. On Army Exercise 1913', 1 October 1913, 'Sub-Section O(a). Office Arrangements', 20 October 1913, WO106/51, TNA.

44 'Notes on Work at General Headquarters, by Capt. Ommanney', 22 October 1913, WO32/4731, TNA. The hectograph was a device that used a gelatine bed or roll to transfer aniline dye from an original document to up to 100 copies. Yates, Control through Communication, 50.
} 
beaten'. ${ }^{45}$ Although it was clear that the IM system outlined in the Staff Manual (War) needed to be revised, the staff exercise in early 1914 was to prove the last opportunity to test the inner-workings of GHQ. Consequently, many of the difficulties encountered during 1913-14 were to resurface during the opening stages of the war.

\section{4-1918: Challenges}

Indeed, problems emerged as soon as the 1914 campaign was underway. According to one GHQ staff officer: 'Difficulties in mobilization, ignorance of each others duties and functions, [and] a tendency to work in watertight compartments made the machine groan and creak considerably'. Messages were often despatched without full knowledge of the situation and 'the crowded room of $\mathrm{O}(\mathrm{a})$ with many persons talking and no one apparently giving a decision produced a feeling akin to despair among the junior members of the Operations Section' ${ }^{46}$ These problems were repeated elsewhere. The staff and signallers in II Corps, for example, struggled to perform their duties on account of having had no pre-war experience working together. ${ }^{47}$ According to one senior signal officer: 'The work seemed to want a little "oiling" at first, owing to the usual staff being augmented and changed, and consequently the work was strange to the majority'. ${ }^{48}$ A similar situation confronted many Territorial and New Army divisions as the BEF grew during $1915-16 .{ }^{49}$ Consequently, with even 'the most competent officers... working on a scale and in conditions of which they had no experience',

\footnotetext{
${ }^{45}$ Unpublished Memoirs, 15, Brigadier-General Sir James Edmonds Papers III/7, Liddell Hart Centre for Military Archives (LHCMA), King's College London.

${ }^{46}$ Peter T. Scott (ed.), 'The View from GHQ: The Second Part of the War Diary of General Sir Charles Deedes', Stand To! Journal of the Western Front Association 11 (1984), 9. For additional context, see Nikolas Gardner, Trial by Fire: Command and the British Expeditionary Force in 1914 (Westport, CT.: Praeger, 2003).

${ }^{47}$ J.P. Harris, Douglas Haig and the First World War (Cambridge: Cambridge UP, 2008), 65-6.

${ }^{48}$ Brigadier-General A.B.R. Hildebrand, 'Second Army Signals, 1914: From the Personal Diary of BrigadierGeneral A.B.R. Hildebrand', Royal Signals Quarterly Journal 6/21 (1938), 131.

${ }^{49}$ K.W. Mitchinson, The Territorial Force at War, 1914-16 (London: Palgrave Macmillan, 2014); Peter Simkins, Kitchener's Army: The Raising of the New Armies 1914-1916 (Manchester: Manchester UP, 1988).
} 
many 'blunders and omissions' occurred during the first half of the war. ${ }^{50}$ During the course of the Somme campaign, one divisional commander complained that because 'officers of the New Army take more time to digest orders and to pass them on to those who have to act on them... in many cases operation orders from higher formations reach Divisional Headquarters 2 hours or less before they have to be acted upon'. Consequently, not only was it often 'too late to act on them' but, as another divisional commander observed, the time delay in getting orders forward 'resulted more than once in futile loss of life'. ${ }^{51}$

Furthermore, 'the rapid rise of both Commanders and Staff Officers with absolutely no Staff experience' contributed to a highly centralised IM system in which many regular officers displayed an open lack of confidence in their civilian subordinates. ${ }^{52}$ Upon his move to Second Army headquarters, Cuthbert Headlam was told by his commanding officer that his predecessor 'was not a [regular] soldier - so of course he did not understand the filing of documents and proper ways of carrying on'. ${ }^{53}$ Similarly, Walter Nicholson testified after the war that " $G$ " had ever a curious dislike of delegating responsibilities'. ${ }^{54}$ This level of prejudice filtered down to the lower levels of command. In October 1916, for example, James Jack was asked by a fellow battalion commander why he continued to draft all important orders and reports himself, even though he had an adjutant to undertake such work. 'The reason', Jack replied, 'is that I know precisely what I want written, and find it easier and quicker to express it personally than to correct the manuscript of another' ${ }^{55}$

\footnotetext{
${ }^{50}$ Captain Pearson Choate to Sir James Edmonds, 6 April 1936, CAB45/132, TNA; Nicholson, Behind the Lines, 170.

51 'Notes on the Recent Operations, 19 Division', 19 July 1916, 'Some Further Notes on the Recent Operations by the Divisional Commander, Major-General Bridges, 19 Division', 9 September 1916, '9 9 th $(S c o t t i s h)$ Division Report', 26 July 1916, Field Marshal Sir Archibald Montgomery-Massingberd Papers 7/3, LHCMA. 52 'Headquarters Units with a Division', 12 December 1918, Lieutenant-General Sir Richard Butler Papers 69/10/1, Imperial War Museum (IWM), London.

${ }^{53}$ Letter to Beatrice, 26 March 1916, in Beach (ed.), The Military Papers, 118.

${ }^{54}$ Colonel W.N. Nicholson, Behind the Lines: An Account of Administrative Staff Work in the British Army 1914-1918 (London: Strong Oak Press, 1989), 185.

55 John Terraine (ed.), General Jack's Diary: War on the Western Front 1914-1918 (London: Cassell, 2001), 172.
} 
It was not just inexperience that created problems. The enormous growth of the BEF, from six infantry divisions and one cavalry division totalling 150,000 men in 1914 , to a peak force of 66 divisions numbering over two million men in $1918,{ }^{56}$ brought with it a dramatic increase in the volume of information generated. This in turn necessitated an IM system which could collect, process and disseminate information 'on an immense and elaborate scale'. ${ }^{57}$ Telegraphically and telephonically, GHQ was 'the nerve-centre of the British Army's activities'. As one signal officer recalled, the telephone traffic at GHQ 'was heavy, the calling-rate high, the holding time long, and the peak loads occurred at unforeseen times' ${ }^{58}$ Throughout 1916, the average delay on the telephone lines from GHQ was two minutes to the frontline, 15 minutes to the Channel bases and 20 minutes to London. ${ }^{59}$ During the final four months of the war, GHQ's signal office handled an average of 6,500 telegrams and 850 telephone calls per day. ${ }^{60}$ These figures reveal exactly what was required to operate what one officer described as 'a far bigger and more intricate business than any industrial concern in peace-time' ${ }^{61}$

Given the prodigious volume of information passing over the army's communications system, an array of problems emerged which were by no means confined to GHQ. For example, XIII Corps Signal Company handled 2,980 telegrams and 1,400 despatch rider messages during the opening 24 hours of the Somme. Combined with the 726 telephone calls taken during the first 12 hours of the attack, the operating staff at the signal

\footnotetext{
${ }^{56}$ Statistics of the Military Effort of the British Empire, 1914-1920 (London: HMSO, 1922), 29-37.

${ }^{57}$ Lieutenant-Colonel J.H. Boraston (ed.), Sir Douglas Haig’s Despatches (London: Dent, 1920), 56.

${ }^{58}$ Captain A. Speight, 'G.H.Q. Signal Office, France', Post Office Electrical Engineers' Journal 13 (1920-21), 48-50.

${ }^{59}$ Scott, 'The Staff', 54.

60 'GHQ and Advanced GHQ Signal Offices, August-November 1918', GHQ Signal Company War Diary, WO95/127, TNA.

${ }^{61}$ Brigadier-General John Charteris, At GHQ (London: Cassell, 1931), 155.
} 
office 'were called upon to work long hours at high pressure'. ${ }^{62}$ During the Battle of Cambrai in November $1917,20^{\text {th }}$ Division's signal office processed over 2,000 messages per day which 'severely taxed the powers of the Signal Company'. ${ }^{63}$ Similarly, on several occasions during $2^{\text {nd }}$ Australian Division's operations in October 1918, the telephone and telegraph circuits "became "choked" resulting in delays to "Urgent Operation" and "Priority" messages'.64

Adding to the pressure of the work performed by signal office personnel was the fact that 'considerable time was spent in transmitting multiple addresses at the end of telegrams to each recipient of the message'. ${ }^{65}$ In 1916, XIII Corps complained that many of the telegrams it dealt with were far too long, calling for 'an elimination of unnecessary words' to speed the process up. Congestion was also regularly experienced at its telephone exchange where operators had been inundated with calls 'which are by no means necessary'. ${ }^{66}$ Similarly, at Messines the following year it was found that the 'urgent operation priority' prefix defeated itself because every officer considered their messages to be 'urgent operation priority'. ${ }^{67}$ Even as late as June 1918, a Third Army memorandum warned that its signal company was being over-worked and rapid-intercommunication impeded because 'the rules laid down... as to the correct use of the telegraph and telephones and [Despatch Rider Letter Service were] not being followed'. It calculated that 10 per cent of telegraph messages were

\footnotetext{
62 'XIII Corps Signal Office during the Offensive on the Somme', n.d., XIII Corps Signal Company War Diary, WO95/906, TNA.

${ }^{63}$ Captain V.E. Inglefield, The History of the Twentieth (Light) Division (London: Nisbet, 1921), 180.

64 'Report on Communications During Period $2^{\text {nd }}$ to $6^{\text {th }}$ October 1918', 16 October 1918, 2 Australian Division Signal Company War Diary, WO95/3296, TNA.

65 'Lessons Learnt from Recent Operations by the Third Army (November 20th to December 6th, 1917)', n.d., WO158/316, TNA.

66 'XIII Corps Signal Office', WO95/906, TNA.

67 'Preliminary Notes on the Operations of the Second Army, June 1917', 7 July 1917, WO158/302, TNA.
} 
unnecessary and that 25 per cent of words within messages 'might be omitted without altering the sense'. ${ }^{68}$

A signal office was therefore 'anything but... tranquil'. ${ }^{69}$ One officer, for instance, described 40 ${ }^{\text {th }}$ Division's signal office in September 1918 as 'a buzzing hive of industry', where personnel worked long hours and under strenuous conditions. ${ }^{70}$ From observing British and French operations in early 1918, a US Army Signal School report stated that 'six hours a day at the instrument out of twenty-four is considered as the maximum for ordinary conditions'. Of the remaining 18 hours, 'operators not on duty should be required to spend five or six hours on repair and upkeep of lines and other odd jobs connected with signal work' ${ }^{71}$ According to one NCO employed at Fourth Army's signal office during 1916: 'It is too much like the usual routine of office work, without any comfort and a marked lack of outdoor exercise' ${ }^{72}$

Frontline signal offices were also under the added pressure of being targeted by enemy artillery. ${ }^{73}$ It was paramount, therefore, that signal offices were suitably positioned. Prior to the Battle of the Somme, Fourth Army issued instructions which stipulated that signal offices were "not to be placed in close proximity to guns, or where it is likely to be subjected to hostile shelling, and where it will be found impossible to use the telephone on account of the noise' ${ }^{74}$ Similarly, American observations of British and French operations led them to conclude that 'Signal Stations must be afforded the best possible protection against shell fire and should be installed in the deepest dugouts available'. They were to be

\footnotetext{
68 'Third Army No. G.34/659', 4 June 1918, RG9-III-C-5/4443/7/6, Library and Archives Canada (LAC), Ottawa.

${ }^{69}$ Hildebrand, 'Second Army Signals', 135.

${ }^{70}$ Diary entry, 30 September 1918, Second-Lieutenant H.A.J. Lamb Papers, PP/MCR/187, IWM.

71 'Lecture No. 33. Trench Signal Stations', 1 May 1918, AEF Army Signal School Files, RG120/405/1794, National Archives and Records Administration (NARA), Maryland.

72 'The Great War Diaries of a Signalman', 9 July 1916, Stapleton Eachus Papers, 01/51/1, IWM.

${ }^{73}$ Lieutenant W.J. Gwilliam, 'A Signal Master on Active Service', Post Office Electrical Engineers' Journal 8 (1915-16), 262.

74 'Notes of a Conference Held at Army Headquarters on 16 April 1916', Fourth Army Records, Vol. 1, IWM.
} 
'placed in positions where they will attract as little attention from the enemy as possible', and be 'properly protected from the effects of gas by utilising gas blankets' and by 'compartmentalising the office'. ${ }^{75}$ This was often easier said than done. Many forward signal offices found it impossible to escape enemy attention, often with tragic consequences. As Reginald Kentish, GOC $76^{\text {th }}$ Infantry Brigade, recalled at the end of July 1916:

Throughout the operations my Headquarters were heavily shelled... Owing to this very heavy shell fire, accompanied as it was by gas and lachrymatory shells, I was compelled to evacuate Headquarters. My Brigade Major was placed hors de combat from the effects of the gas, my Signal Officer was killed and several of my Staff killed and wounded. All my communications were cut. ${ }^{76}$

In light of such occurrences, commanders at all levels experienced the extraordinary difficulty of obtaining prompt and reliable information. As a frustrated Sir Douglas Haig told Claud Jacob, GOC II Corps, in August 1916, ‘information from divisions frequently reaches HQs of corps, armies and GHQ very slowly. Too slowly! ${ }^{77}$ How, and with what success, then, did the BEF attempt to overcome these problems?

\section{4-1918: Adaptation}

Owing to the scale and intensity of trench warfare and the increasing number of formations in the field, the mounting volume of information generated by the BEF necessitated changes to its IM system. As James Jack noted in October 1916: 'The amount of office work is inconceivable. One can now comprehend the significance of the dictum, "the pen is mightier

\footnotetext{
75 'Lecture No. 33', RG120/405/1794, NARA.

76 'The Situation Which Often Confronts Brigadiers When Headquarters are Situated Close up to the Front Line', 26 July 1916, Montgomery-Massingberd Papers 7/3, LHCMA.

${ }^{77}$ Field Marshal Haig Diary, 14 August 1916, WO256/12, TNA; Gary Sheffield and John Bourne (eds.), Douglas Haig War Diaries and Letters 1914-1918 (London: Phoenix, 2006), 220.
} 
than the sword", as the swords are dying or becoming worn out while the pens keep driving on with increasing rapidity'. ${ }^{78}$ One such change involved the proliferation of modern bureau technologies, such as typewriters and duplicating machines, and the introduction of new processing techniques, such as card index filing systems, in order to improve the speed and efficiency of office work. As Sydney Partridge, the Director of Army Printing and Stationary Services, noted in March 1916:

The written message has replaced the verbal message; the duplicator and typewriter have eliminated altogether the group of "copyists"; the Sunprinting Apparatus has reduced the number of draughtsmen; the "Addressograph" has cut down the "Despatch Room" by 90\%; the "Dictaphone" has replaced the shorthand writer; and the Calculator and Comptometer have revolutionised the Counting House.

Partridge concluded that it was the duty of every unit 'seeking efficiency and economy in office administration to strike the balance between the "human" and the "mechanical", yet the more efficiently a Department is organised the greater will be the tendency for “mechanical" to encroach on "human" territory' ${ }^{79}$ As early as December 1914, for instance, Partridge had noted that there was already 'a great demand for typewriting machines and duplicating apparatus for units with the Expeditionary Force' ${ }^{80}$ To place the significance of these demands into context, in the aftermath of the army manoeuvres that had taken place just over a year previously, Sir Henry Wilson had complained about the shortage of pencils

\footnotetext{
${ }^{78}$ Terraine, (ed.), General Jack's Diary, 172.

79 'Memorandum for the A.G. on Economy in Personnel Employed in Office Administration', 8 March 1916, WO95/81, TNA.

${ }^{80}$ Director of Army Printing and Stationary Services War Diary, 29 December 1914, WO95/81, TNA. On the use of typewriters for the dissemination of British tactical doctrine, see: Paddy Griffith, Battle Tactics of the Western Front: The British Army's Art of Attack 1916-18 (London: Yale UP, 1994), 180-81.
} 
for the General Staff office at GHQ. ${ }^{81}$ However, typewriters were expensive and in early 1915, with supply unable to meet demand, all requests had to be 'supported by definite reasons justifying issue of a machine' ${ }^{82}$

Gradually the army was supplied with greater numbers of typewriters. ${ }^{83}$ However, there is evidence to suggest that even during the last two years of the war some units found them difficult to come by. Upon finding his brigade headquarters 'up to their necks' in paperwork on the eve of the Battle of Messines, for example, one artillery officer 'promised to lend them for a few days [his] private Corona Typewriter to enable them to cope with this flood-tide of paper' ${ }^{84}$ Similarly, as a junior captain in 1914, James Jack noted in his diary at the Battle of Mons that he, along with the other battalion captains in the $19^{\text {th }}$ Infantry Brigade, 'write the orders dictated by the brigadier on our small Field Service notebooks (6 by 4 inches), each making three carbon copies. These orders are shortly sent to battalions by their orderlies on pedal bicycles'. Four years later, as GOC $28^{\text {th }}$ Infantry Brigade, Jack recorded the conversation he had with Herbert Plumer, GOC Second Army: 'The General asks how the Brigade is getting on, and laughs - a little uncomprehendingly - when I put a typewriting machine as our first requirement. This is not so frivolous a request as it sounds [because]... manuscript is too slow for the volume of office work' ${ }^{85}$ By the end of the war there were approximately 5,000 typewriters being used in the BEF, with a dedicated service of travelling mechanics on motorcycles and workshops in each army area to oversee

\footnotetext{
81 'Sub-Section O(a)', 20 October 1913, WO106/51, TNA.

${ }^{82}$ Director of Army Printing and Stationary Services War Diary, 29 March 1915, WO 95/81; 'Stationery Services, Lines of Communication, British Expeditionary Force in France: Enlistment of Additional Typewriter Mechanics, 1915', T1/11846, TNA.

83 The US-made Corona typewriter was used extensively by the British during the war. See Wilfred A. Beeching, Century of the Typewriter (London: Heinemann, 1974), 37.

${ }^{84}$ Neil Fraser-Tytler, Field Guns in France (London: Hutchinson, 1922), 178.

${ }^{85}$ Terraine, (ed.), General Jack's Diary, 29, 265; John Baynes, Morale: A Study of Men and Courage (New York: Avery, 1988), 246-7.
} 
typewriter repair and maintenance. ${ }^{86}$ As Partridge informed the War Office in August 1918, typewriters had become 'a necessity, not a convenience' ${ }^{87}$

Similarly, in a series of letters written to a newly appointed battalion adjutant concerning the nature of his duties, an unnamed officer strongly advised that he utilise a card index filing system in order to cope with the influx of information that he and his office clerks would undoubtedly have to deal with. ${ }^{88}$ The benefits of such a system were made clear in a post war article:

Now supposing we had a little box on our desk, about six inches by six by four; and we could nonchalantly turn back the lid, and flick some scores of little postcards therein until we came to an alphabetical index card $S$; and supposing we glanced rapidly through a dozen, or less, cards immediately behind $\mathrm{S}$; we could in a very few seconds have a large amount of concentrated information... at our finger tips. ${ }^{89}$

Not only did many of the BEF's administrative and support services come to value card indexes, ${ }^{90}$ but certain combat elements also made effective use of them, most notably for counter-battery work. ${ }^{91}$ Since rapid communication to and from a variety of intelligence sources was paramount to the success of counter-battery fire, the arrangements within each corps-level Counter Battery Staff Office (CBSO) were 'systemized' so that 'several hundred items of information' could be collected,

${ }^{86}$ J.E. Edmonds, Military Operations, France and Belgium, 1916, Vol. 1 (London: HMSO, 1932), 131.

${ }^{87}$ Director of Army Printing and Stationary Services War Diary, 8 August 1918, WO95/81, TNA.

${ }^{88}$ These letters were written during the war and published anonymously as: CIX, 'Letters to an Adjutant', Army Quarterly, 8/1-2 (1924), 31-44, 274-85.

${ }^{89}$ Lieutenant G.V. Micklam, 'The Personal Card Index, or Moderated Methodism', Royal Engineers Journal, 43 (1929), 636-7.

${ }^{90}$ Beach, Haig's Intelligence, 171; Fox, Learning to Fight, 197-9.

${ }^{91}$ Albert Palazzo, 'The British Army's Counter-Battery Staff Office and Control of the Enemy in World War 1', Journal of Military History, 63/1 (1999), 55-74; Sanders Marble, British Artillery on the Western Front in the First World War (London: Routledge, 2013), 167-70. 
processed and disseminated in the quickest and most effective way possible. ${ }^{92}$ To this end, 'suspect cards', detailing information concerning the location of unconfirmed enemy batteries, were indexed and found to be a 'quick' and 'infinitely preferable' means of recording and storing information. ${ }^{93}$ In light of the centrality of accurate indirect artillery fire to the First World War RMA, it stands to reason that the IM techniques of the CBSO acted as a critical force enabler.

Other equipment deemed 'essential' for the efficient running of the CBSO included a typewriter, duplicator and telephone switchboard. ${ }^{94}$ The latter had become a permanent feature of British signal offices from January 1916 when one 20-line and one 10-line switchboard per division was authorised. ${ }^{95}$ Larger switchboards for corps and army headquarters were also designed, mainly as a result of the Signal Service's close affiliation with the General Post Office (GPO). In all, the latter furnished the BEF with 36,000 switchboards and 10,000 portable exchanges, equipment deemed vital in terms of managing the ever-growing volume of telephone traffic. ${ }^{96}$ During the second week of June 1917, for example, the Canadian Corps' 60-line exchange averaged between 4,000 and 5,000 calls per day, while the Australian Corps headquarters' 90-line switchboard averaged 161 calls per hour throughout August $1918 .{ }^{97}$

\footnotetext{
92 Brigadier-General A.G.L. McNaughton, 'Counter Battery Work', Canadian Defence Quarterly, 3/4 (1926), 385.

93 'Remarks on "Notes on the Work of a Counter Battery Office"', n.d. [c. 1917], Lieutenant-General Sir Herbert Uniacke Papers U/VIII/9, Royal Artillery Institution (RAI).

94 'Notes on Counter Battery Work in Connection with the Capture of Vimy Ridge by Canadian Corps, April $9^{\text {th }}, 1917$ ', WO95/1059, TNA.

${ }^{95}$ Priestley, Work of the Royal Engineers, 64.

${ }^{96}$ Anon., 'Complimentary Dinner to Sir Andrew Ogilvie', Post Office Electrical Engineers' Journal, 13 (192021), 70-71; 'Organisation of the Signals of an Army when Holding a Sector of Line (Siege Warfare)', n.d. [c. 1918], Organisation and Work of Signals in WW1 - Papers on Various Subjects, M1599, Royal Engineers Museum Archive (REMA), Gillingham.

97 'Signal Service, Canadian Corps', 14 June 1917, RG9-III-C-5/4438/1/1, LAC; 'War Diary, Month of August 1918, Headquarters Section, Australian Corps Signal Company’, AWM4-22/10/6, Australian War Memorial (AWM), Canberra.
} 
However, improving the BEF's IM system was not simply a matter of employing the latest bureau technologies but also of developing the infrastructure to deal with information as efficiently as possible. As the Manual of Army Signal Service - War made clear, 'if messages are to be rapidly dealt with, and the several means of communication co-ordinated, the terminals of the message routes must be carefully organized'. ${ }^{98}$ To this end, each level of command established its own signal office which acted as 'a radiating point' to the rest of the army. ${ }^{99}$ The ideal signal office would group, where possible, telegraph, telephone and wireless operators within close proximity of each other so as to 'greatly facilitate supervision and rapidity of despatch, ${ }^{100}$ whilst despatch riders and orderlies were allotted a separate room so as to 'minimise interference with office routine'. ${ }^{101}$

Yet, the nature of the fighting on the Western Front demonstrated 'the impossibility of trying to control the day-to-day operations of small bodies of men in a shelled trench area from Corps or Division HQ, unless the latter are at least as near to what is going on as Brigade HQ' ${ }^{102}$ Thus, orders, reports and other messages were also likely to pass through observation stations, advanced headquarters and report centres. Observation stations enabled a commander and his staff 'to obtain a good view of the ground, over which his troops are working, from a position from which he can communicate his orders and instructions to his subordinates..., or report the progress of the fight to his superiors' ${ }^{103}$ Perhaps the most notable use of observation stations occurred on 1 July 1916 when both Thomas Morland, GOC X Corps, and Oliver Nugent, GOC $36^{\text {th }}$ Division, established forward observation posts

\footnotetext{
${ }^{98}$ Manual of Army Signal Service - War (Provisional) (London: HMSO, 1914), 30.

${ }^{99}$ Corporal Frederick Arthur Sanders, Interview (1984), 008273/04, Department of Sound Records, IWM.

${ }^{100}$ Manual of Army Signal Service, 33.

${ }^{101}$ Priestley, Work of the Royal Engineers, 190.

${ }^{102}$ Lieutenant-Colonel William Newton to Sir James Edmonds, [?] 1936, CAB45/136, TNA.

103 'Position of Corps and Divisional Advanced Report Centres and Observation Stations for Corps and Divisional Commanders', 12 March 1916, Fourth Army Records, Vol. 7, IWM.
} 
in the tops of trees from which they could observe the German lines and watch the course of events as they unfolded. ${ }^{104}$

Much greater use was made of advanced headquarters and report centres which were established by each formation so as 'to facilitate the rapid transmission of information required for the conduct of tactical operations'. ${ }^{105}$ Their main purpose was 'to place... commanders and staff in a position whence it will be easy for them to reach, or communicate rapidly with D.R. with, subordinate and neighbouring formations'. ${ }^{106}$ Attempts to capture this best practice and codify it into formal, written doctrine were made, most notably in the aftermath of Second Army's success at Messines in June 1917 which owed a great deal to the employment of a thorough IM system, details of which provide revealing insights into not only how British headquarters handled information during the second half of the war but also how the BEF sought to learn from its experiences. ${ }^{107}$

At the heart of Second Army's communications system at Messines was the establishment of a Forward Army Report Centre at Locre, situated approximately four miles from the frontline. ${ }^{108}$ The purpose of the Centre was to ensure that information from all available sources concerning the progress of the battle was obtained in the quickest manner possible and that such information was swiftly processed and disseminated to the relevant formations concerned. ${ }^{109}$ The Locre château was chosen on account of its central location and the fact that it already housed a large telephone exchange on a specially constructed trunk line. The Centre was therefore in direct telephonic communication with the general

\footnotetext{
104 Letter to Margie, 4 July 1916, in Bill Thompson (ed.), General Sir Thomas Morland: War Diaries \& Letters, 1914-1918 (Kibworth Beauchamp: Matador, 2015), 148-9; Nugent to his son, 27 June 1916; Nugent to his wife, 30 June 1916, in Nicholas Perry, (ed.), Major-General Oliver Nugent and the Ulster Division 19151918 (Stroud: Sutton, 2007), 94-5.

105 'Second Army. O.A. 766. 1217/G', 19 March 1915, WO157/303, TNA.

106 'Position', Fourth Army Records, Vol. 7, IWM.

${ }^{107}$ For Messines, see Ian Passingham, Pillars of Fire: the Battle of Messines Ridge, June 1917 (Stroud: Sutton, 1998).

108 J.E. Edmonds, Military Operations, France and Belgium, 1917, Vol. 2 (London: HMSO, 1948), 43; Charles Harington, Plumer of Messines (London: John Murray, 1935), 101.

109 'Second Army. Report on Army Centre. Battle of Messines, June 1917', 20 June 1917, WO158/305, TNA.
} 
staff office at Second Army headquarters at Cassel, ${ }^{110}$ as well as the headquarters of corps, RFC, artillery and anti-aircraft formations. ${ }^{111}$ Each corps also established a report centre which was connected both to the Army Centre and to divisional headquarters. ${ }^{112}$

Information was also to be obtained from runners, despatch riders and a Wireless Interception Section. The latter was operated by the Army Wireless Company and any information secured went straight to the Army Wireless Intelligence Officer and his staff, where messages were deciphered and the contents analysed before being made available to the Operations branch, who rapidly despatched the information to the formations concerned. ${ }^{113}$ A designated 'dropping zone' for messages from contact aeroplanes was also established within close proximity of the Report Centre. By this means, information concerning troop movements, including those of the enemy, could be ascertained. As information from these various sources arrived at the centre, 'it was classified and an immediate decision made as to whom it affected; it was then forwarded or re-issued to the formations concerned, through Corps Centres in the case of Corps, or direct in the case of Corps Heavy Artillery, etc.'. ${ }^{114}$

Although the Report Centre was in operation for only two weeks, it demonstrated itself to be of great value, keeping Second Army headquarters 'informed constantly and promptly of what was taking place, not only on the front, but far behind the enemy's lines'. ${ }^{115}$ From Dawn till midnight on 7 June, the centre handled a total of 542 messages. ${ }^{116}$ The Corps Report Centres were equally successful. According to a US Army Staff College

\footnotetext{
${ }^{110}$ Harington, Plumer, 101.

${ }^{111}$ Second Army Signal Company War Diary, 28 May-2 June 1917, WO95/288, TNA.

${ }^{112}$ Edmonds, Military Operations, 1917, Vol. 2, 43; 'Second Army Offensive. Xth Corps Instructions. Appendix VII. Corps Advanced Intelligence Report Centre’, 27 May 1917, X Corps War Diary, WO95/852, TNA.

${ }^{113}$ Beach, Haig's Intelligence, 166.

114 'Second Army. Report on Army Centre', WO158/305, TNA.

115 Ibid.

116 'Appendix II. Messages Received and Transmitted During June $7^{\text {th }}-$ Battle of Messines', WO158/305, TNA.
} 
report in early 1918, the 'Corps Information Centres' at Messines 'reduced [the] duplication of messages and the overloading of Signal Communications, and ensured that information received from all sources [was] summarised and forwarded as soon as possible to all concerned'. ${ }^{117}$ As one signal officer stated after the battle, 'the extra trouble taken in providing the necessary organisation for quickly disseminating information... seems to have been fully repaid'. 118

In a rather modest assessment of the Army Report Centre, Tim Harington, MGGS Second Army, informed his Fourth Army counterpart that although 'we got great value from it... we really only gave it a trial at very short notice and it is capable of much improvement'. ${ }^{119}$ John Fowler, the Director of Army Signals, however, was more upbeat. Realising the contribution the Report Centre had made to Second Army's success at Messines, Fowler issued a memorandum to the other armies stating that 'a similar system will be required in all future operations on a large scale, and it should be taken into account when planning communications'. ${ }^{120}$ Copies of the report detailing the inner-workings of the Report Centre were also distributed throughout the army in an attempt to establish some sort of common practice. ${ }^{121}$ Indeed, some formations did later implement very similar IM systems. At the Battle of Cambrai in November 1917, for instance, Third Army headquarters established an 'Information Bureau' in order to expedite the transmission of information within its General Staff office. ${ }^{122}$ A similar 'Information Bureau' was set up in 'a marquee on the lawn in front of the Headquarters offices' of the Australian Corps prior to the Amiens

\footnotetext{
117 'A System in Use by a British Corps for Dealing with Reports', January 1918, AEF Staff College Files, RG120/362/1978, NARA.

118 'Report on Signal Communications During Recent Offensive Operations on IX Corps Front', n.d., IX Corps Signal Company War Diary, WO95/845, TNA.

119 'Tim Harington to Archibald Montgomery', 6 July 1917, Montgomery-Massingberd Papers 7/35, LHCMA.

120 'Signal Notes No. 8', 15 June 1917, Director of Army Signals War Diary, WO95/57, TNA.

${ }^{121}$ Copies of the report can be found in: Montgomery-Massingberd Papers 7/35, LHCMA; and, Sir Arthur Currie Papers, MG30, E100/35/160, LAC.

122 'Distribution of Duties during Operations', 15 November 1917, WO158/316, TNA.
} 
offensive in August 1918, where liaison officers were to 'make all enquiries for information as to the progress of the operations'. ${ }^{123}$ These successes appear to have resonated with the BEF's doctrine writers, for the November 1918 edition of SS.135 The Division in Attack made explicit reference to the use of 'central information bureaux' for coordinating the newly-formed Royal Air Force's (RAF's) ground support operations with artillery and tank formations. ${ }^{124}$ According to one former officer-turned official historian, the central information bureau in use by the RAF during late August 1918 'was a nearly perfect parallel to the army's eyes registering to the army's brain'. ${ }^{125}$

Despite these successes, it is clear that although attempts to instil an IM doctrine throughout the BEF were made, in practice it was applied unevenly and inconsistently. As Tim Harington informed Sir Henry Wilson in July 1918, 'very divergent views are held and entirely different methods exist in the various Armies, Corps and Divisions'. ${ }^{126}$ One staff officer, who worked at GHQ, corps and divisional headquarters, for instance, recalled that at both GHQ and corps 'we worked by lengthy precisely worded correspondence, whereas in a division we talked on the telephone - and there is a world of difference in the two methods'. Although there was some commonality, each headquarters 'had a completely different method of office work' ${ }^{127}$ The BEF's approach towards IM, therefore, provides further evidence to support the argument that the army's methods for learning, and thus its ability to adapt, were shaped to a considerable degree by its long-standing preference for pragmatic solutions, whereby codification of best practice occurred but it was left to individuals to

\footnotetext{
123 'Battle Instructions No. 19. Liaison', 6 August 1918, Field Marshal Sir John Dill Papers 1/9, LHCMA. See also: 'Office Memorandum No. 13. Corps Report Centre', 6 August 1918, AWM4-22/10/6, AWM.

${ }^{124} \mathrm{Jim}$ Beach (ed.), SS. 135. The Division in the Attack - 1918 (Strategic and Combat Studies Institute, The Occasional, No. 53, 2008), 92-3.

${ }^{125}$ F.M. Cutlack, The Australian Flying Corps in the Western and Eastern Theatres of War 1914-1918 (Sydney: Halstead Press, 1923), 314. See also: H.A. Jones, The War in the Air: Being the Story of the Part Played in the Great War by the Royal Air Force, Vol. 6 (Oxford: Clarendon Press, 1928), 474-5.

${ }^{126}$ Quoted in Simon Robbins, British Generalship on the Western Front 1914-18: Defeat into Victory (London: Frank Cass, 2005), 36.

${ }^{127}$ Nicholson, Behind the Lines, 302-3, 22.
} 
accept, reject or modify it in order to suit local conditions and individual circumstances. ${ }^{128}$ Far from a principal source of weakness, however, this 'cult of pragmatism, flexibility and an empirical approach' played an important part in ensuring the British army defeated its German adversary in the summer and autumn of $1918 .{ }^{129}$ As a report by the $3^{\text {rd }}$ Canadian Brigade Signal Section in mid-August 1918 made clear, during the course of the recent Battle of Amiens 'many of our ideas were revolutionized and... for communications in open warfare, an absolute breakaway from trench warfare systems [was] necessary and entirely different methods... employed. Luckily, our signallers excelled in adaptability and... became accustomed to... the new era in warfare' ${ }^{130}$

\section{Conclusion}

In a lecture given to newly appointed officers of the American Expeditionary Force (AEF) in early 1918, Captain Stephen Walmsley, a Signal Corps instructor, stated that since 'the enormous number of messages to be handled and the vital importance of many of them makes careful and accurate handling essential', American officers would do well to follow those methods for processing information 'which had been found necessary' by their British counterparts. ${ }^{131}$ Walmsley went on to liken the BEF's CIS 'to the systems existing in large industrial organizations in the United States, where all factories, warehouses, sub-offices and apartments have their telephone or telegraph lines leading directly or indirectly to the head

\footnotetext{
${ }^{128}$ Fox, Learning, 240-50.

${ }^{129}$ Gary Sheffield, 'Doctrine and Command in the British Army: An Historical Overview', E-2, in Army Doctrine Publication (ADP). Operations (2010), < https://www.gov.uk/government/uploads/system/uploads/attachment_data/file/33695/ADPOperationsDec10.pd f >; Brown, British Logistics, 231-40; Boff, Winning and Losing, 249.

130 ' $3^{\text {rd }}$ Battle of the Somme. August $8^{\text {th }}, 1918$-August $13^{\text {th }}, 1918^{\prime}$ ', n.d., RG9-III-D-3/5005/693, LAC.

131 'Lecture No. 3. Handling of Messages', Officers' School - First Course, Monday, January $7^{\text {th }}, 1918$ to Saturday, February $2^{\text {nd }}, 1918$, RG120/404/2, NARA.
} 
offices'. ${ }^{132}$ As one junior staff officer at GHQ noted, during the last two years of the war the BEF was being run like 'an up-to-date competitive business'. ${ }^{133}$ Indeed, the growing scale, complexity and intensity of the fighting on the Western Front forced the BEF to embrace IM structures, techniques and technologies that were already becoming prevalent in pre-war business circles. By examining the internal mechanisms that headquarters put in place for dealing with large volumes of information and by mapping the vertical and horizontal channels that information flowed through headquarters, this article has shown that as the war progressed British commanders sought newer and better ways to gather, process and disseminate information. By embracing new office technologies, such as typewriters and telephone switchboards, new techniques like card indexes, and by refining its IM infrastructure, most notably with the establishment of report centres and information bureaus, the BEF developed a more flexible, robust and sophisticated IM system which, though by no means perfect, helped pave the way for the successes of the summer and autumn of $1918 .^{134}$

These findings have wider implications for our understanding of the British army's ability to learn and adapt between 1914 and 1918, the nature of the supposed First World War RMA, and the IM challenges faced by today's armed forces. First, the case of British IM during the First World War reinforces the arguments of recent historians that the BEF's methods for learning were more diverse and multifaceted than hitherto thought. Attempts to improve IM throughout the army by sharing knowledge of the inner-workings of Second Army's Report Centre at Messines in 1917, for instance, highlights the BEF's use of 'non-

132 'Lecture No. 1. Signals in the Present War, Officers' School - Second Course, Monday, February 11, 1918 to Saturday, March 23, 1918', RG120/404/3, NARA.

133 "GSO" [Frank Fox], GHQ (Montreuil-sur-Mer) (London: Philip Allan, 1920), 230.

${ }^{134}$ Robin Prior and Trevor Wilson, Command on the Western Front: The Military Career of Sir Henry Rawlinson, 1914-1918 (Oxford: Blackwell, 1992), 289-391; J.P. Harris with Niall Barr, Amiens to the Armistice: The BEF in the One Hundred Days' Campaign, 8 August-11 November 1918 (London: Brassey's, 1998). 
formal' and 'horizontal' learning methods. ${ }^{135}$ However, the manner in which the subsequent employment of information bureaus was encapsulated in written doctrine in 1918 demonstrates that the BEF was capable of embracing more 'formal', 'vertical' approaches as well. ${ }^{136}$ Undoubtedly this lack of consistency in approach and practice created difficulties, contributing to some of the BEF's most notable failures. Nevertheless, although problems concerning the speed, reliability, capacity and integrity of its CIS persistently undermined British operations, on the whole the BEF's underlying ethos fostered a diverse, flexible and pragmatic approach that enabled it to successfully adapt to the challenges of modern warfare. As one signal officer reported in August 1918, 'an ounce of practice is far better than a ton of theory'. ${ }^{137}$

Second, a closer examination of the BEF's CIS reveals that the BEF had a greater awareness of, and appreciation for, IM than historians have recognised. In fact, given that 'the systematic collection, processing and dissemination of information in organisations are core features of modernity', ${ }^{138}$ it stands to reason that if an RMA did indeed transpire during the course of the war, giving birth to the 'Modern Style of Warfare', then it depended crucially upon its IM components to succeed. By 1918 the BEF had developed a relatively efficient CIS that was capable of transmitting and receiving large volumes of information, which in turn was used to coordinate successful, limited-objective, combined arms operations. ${ }^{139}$ But transmitting and receiving was not enough; a proficient IM system was also required to process the information effectively. The evidence presented here suggests

\footnotetext{
${ }^{135}$ Foley, 'Dumb Donkeys', 279-98; Robert Foley, 'A Case Study in Horizontal Military Innovation: The German Army, 1916-1918', Journal of Strategic Studies 35/6 (2012), 799-827.

${ }^{136}$ Fox, Learning, 242-44. This point is further reinforced by the manner in which the BEF's first communications doctrine manual, SS.148 Forward Inter-Communication in Battle (March 1917), was developed. See Hall, Communications, 83-6, 303-5. On British doctrine more generally, see Jim Beach, 'Issued by the General Staff: Doctrine Writing at British GHQ, 1917-1918', War in History, 19/4 (2012), 464-91. 137 ' $3{ }^{\text {rd }}$ Battle of the Somme', RG9-III-D-3/5005/693, LAC.

${ }^{138}$ Black and Brunt, 'Information Management', 362.

${ }^{139}$ Hall, Communications, 298-99.
} 
that the demands of fighting a modern war resulted in a general, but not universal, improvement in the BEF's IM techniques, incorporating both traditional characteristics and revolutionary features, which in turn laid the groundwork, albeit in embryonic form, for the IM systems of modern armies.

Indeed, there is evidence to suggest a degree of continuity in the IM practices of the British army from the First World War through the interwar period and into the Second World War. The 1932 'Report of the Committee on the Lessons of the Great War', for instance, recognised the importance of good communications and the value of having headquarters situated further forward so that information could reach commanders more quickly and that information be processed and disseminated in a speedier and more efficient manner. ${ }^{140}$ The subsequent 1935 Field Service Regulations stressed the need for formations to establish 'signal centres', very similar in nature to the information bureaus and report centres of the BEF, with the likewise aim of facilitating messages between a headquarters and a subordinate formation, economising in personnel and material. ${ }^{141}$ Such signal centres were employed to good effect during the Second World War. ${ }^{142}$ Furthermore, given that the AEF studied British and French fighting methods closely in order to help bring them up to speed in 1917-18, there are reasonable grounds for arguing that some of the IM practices of the BEF influenced future American practice as well. ${ }^{143}$ The US Army's 1923 Field Service Regulations, for example, also stipulated the need for 'advanced message centres' which

\footnotetext{
140 'Report of the Committee on the Lessons of the Great War, The War Office 1932', WO32/3116, TNA.

${ }^{141}$ Field Service Regulations, Vol. II. Operations (London: HMSO, 1935), 36.

${ }^{142}$ Simon Godfrey, British Army Communications in the Second World War: Lifting the Fog of Battle (London: Bloomsbury, 2013), 126-7, 177.

${ }^{143}$ David W. Hogan, Jr., A Command Post at War: First Army Headquarters in Europe, 1943-1945

(Washington D.C.: Center of Military History, United States Army, 2000), 4-5.
} 
would serve 'as a means of economizing the number of men employed in the transmission of messages and increases rapidity and certainty in transmission' ${ }^{144}$

With these examples in mind, third, and finally, it is hoped that this article will resonate with current practitioners, having provided insight into how IM was practiced by their predecessors one hundred years ago, and by highlighting some of the building blocks upon which later IM doctrine and practice was based. Although significant technological advances have 'enabled greater storage and manipulation of information' to be 'transferred almost instantaneously, over greater range, in greater volume and in a variety of formats', ${ }^{145}$ many of the IM challenges faced by today's armed forces, including information overload, interoperability and security, bare striking resemblance to those experienced by the BEF. ${ }^{146}$ Indeed, many of the methods employed in recent years by British and American forces to overcome these IM challenges can trace their origins back to the First World War. In July 2004, for example, the inability of Stanley McChrystal and Task Force 16 to send and receive 'vast amounts of classified information... fast enough to make it relevant to targeting', resulted in the establishment of a Situational Awareness Room in Balad, Iraq, which encouraged McChrystal and his team to 'deliberately craft... work spaces to channel interaction, force collaboration, and ease the flow of people and information', much like the report centres and information bureaus of the BEF did in 1917-18. ${ }^{147}$

Thus, although the First World War occurred one hundred years ago, a close examination of the BEF's IM practices can reveal lessons of contemporary relevance. The primary lesson that can be gleaned from this case study is that a 'one size fits all' approach is

\footnotetext{
${ }^{144}$ Field Service Regulations, United States Army, 1923 (Washington D.C.: Government Printing Office, 1924), 28-9.

145 JCN 2/12, Future Land Operating Concept (May 2012), 2-15.

146 JDP 6-00, Communications, 1-3-5; Theo Farrell, Sten Rynning and Terry Terriff, Transforming Military Power Since the Cold War: Britain, France, and the United States, 1991-2012 (Cambridge: Cambridge UP, 2013), 137-43.

${ }^{147}$ General Stanley McChrystal, My Share of the Task: A Memoir (New York: Portfolio/Penguin, 2014), 15052.
} 
to be avoided if British and American armed forces are to reap the benefits of an effective IM system. The recent announcement that the British tactical communications system, BOWMAN, is to be replaced by an updated and more flexible Tactical Communication and Information Systems (TacCIS) platform, known as MORPHEUS, demonstrates the significance that the British armed forces attaches to providing commanders with better information superiority on the battlefield. ${ }^{148}$ Much like the First World War RMA, however, the ongoing information-based RMA will require not just the implementation of the latest technological advancements but also a great deal of institutional and doctrinal adaptation. ${ }^{149}$ Given the varied and expanding roles that Western armed forces are having to perform and prepare for, whether they be counterinsurgency, peacekeeping and stabilisation missions in the Middle East and Africa, or the prospect of conventional operations on European soil, ${ }^{150}$ a flexible and pragmatic approach, similar to that espoused by the BEF in 1914-18, is likely to result in a more effective IM system capable of successfully adapting to the myriad of twenty-first century challenges.

\footnotetext{
${ }^{148}$ Ministry of Defence, 'Morpheus Programme: Next Generation Tactical Communication Information Systems for Defence', last updated 18 April 2018, <https:/www.gov.uk/guidance/morpheus-project-nextgeneration-tactical-communication-information-systems-for-defence >

${ }^{149}$ Sean Ryan, 'Finding the Right Answer: Adapting Military Intelligence to the Information Age', RUSI Journal 160/4 (2015), 50-8; Brad Spiel, 'Less is More: The Enabled Combat Brigade Headquarters' (5 January 2018), < https:/groundedcuriosity.com/less-is-more-the-enabled-combat-brigade-headquarters/ > .

${ }^{150}$ General Sir Nicholas Carter, 'Dynamic Security Threats and the British Army' (Speech Given at the Royal United Services Institute, 22 January 2018), < https://www.gov.uk/government/speeches/dynamic-securitythreats-and-the-british-army-chief-of-the-general-staff-general-sir-nicholas-carter-kcb-cbe-dso-adc-gen >.
} 
Figure 1. Inner-working of Operations Section, General Staff Branch, GHQ, $1914^{151}$

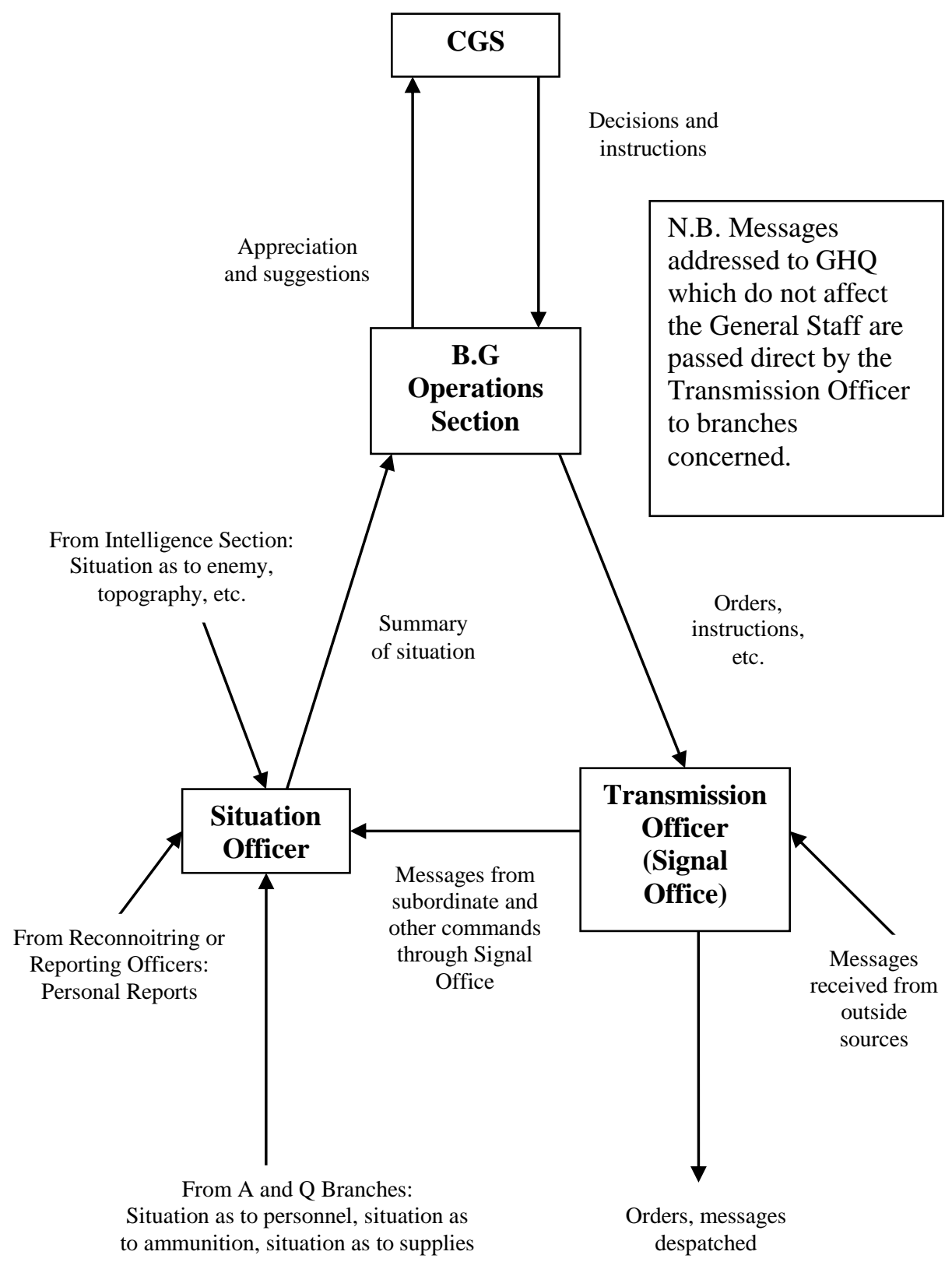

${ }^{151}$ Compiled from 'Remarks on Staff Manual, War, 1912', WO32/4731, TNA. 


\section{Bibliography}

Alberts, David S., and Richard E. Hayes, Understanding Command and Control (Washington: CCRP, 2006).

Amery, L.S., The Times' History of the War in South Africa 1899-1902, Vol. III (London: Sampson Low, 1902).

Anon., 'Complimentary Dinner to Sir Andrew Ogilvie', Post Office Electrical Engineers' Journal, 13 (1920-21), 70-71.

Bailey, Jonathan, 'The First World War and the Birth of Modern Warfare', in MacGregor Knox and Williamson Murray (eds.), The Dynamics of Military Revolution 13002050 (Cambridge: Cambridge UP, 2001), 132-53.

Baynes, John, Morale: A Study of Men and Courage (New York: Avery, 1988).

Beach, Jim (ed.), The Military Papers of Lieutenant-Colonel Sir Cuthbert Headlam, 19101942 (Stroud: History Press for the Army Records Society, 2010).

(ed.), SS. 135. The Division in the Attack - 1918 (Strategic and Combat Studies Institute, The Occasional, No. 53, 2008).

'Issued by the General Staff: Doctrine Writing at British GHQ, 1917-1918', War in History, 19/4 (2012), 464-91.

Haig's Intelligence: GHQ and the German Army, 1916-1918 (Cambridge: Cambridge UP, 2013).

Beeching, Wilfred A., Century of the Typewriter (London: Heinemann, 1974).

Beniger, James, The Control Revolution: Technological and Economic Origins of the Information Society (Cambridge, MA.: Harvard UP, 1986).

Biddle, Stephen, Military Power: Explaining Victory and Defeat in Modern Battle (Princeton: Princeton UP, 2004).

Black, Alistair, and Rodney Brunt, 'Information Management in Business, Libraries and British Military Intelligence: Towards a History of Information Management', Journal of Documentation 55/4 (1999), 361-74.

Black, Alistair, Dave Muddiman and Helen Plant, The Early Information Society: Information Management in Britain before the Computer (Aldershot: Ashgate, 2007).

Black, John, 'Behind the Scenes with the Pen and Ink Corps! The Role of the Army Pay Services during the Great War in Maintaining the Loyalty of the Fighting Soldier and Preserving the Social Fabric of the United Kingdom', War \& Society 35/3 (2016), 180-203.

Boff, Jonathan, Winning and Losing on the Western Front: The British Third Army and the Defeat of Germany in 1918 (Cambridge: Cambridge UP, 2012).

Boraston, Lieutenant-Colonal J.H. (ed.), Sir Douglas Haig's Despatches (London: Dent, 1920).

Broadberry, Stephen, and Sayantan Ghosal, 'From Counting House to the Modern Office: Explaining Anglo-American Productivity Differences in Services, 1870-1990', Journal of Economic History 62/4 (2002), 967-98.

Brown, Ian Malcolm, British Logistics on the Western Front 1914-1919 (Westport, CT.: Praeger, 1998).

Bucholz, Arden, Moltke, Schlieffen and Prussian War Planning (Oxford: Berg, 1993). 
Bullock, Mike, and Laurence A. Lyons, Missed Signals on the Western Front: How the Slow Adoption of Wireless Restricted British Strategy and Operations in World War I (Jefferson, NC.: McFarland \& Company, 2010).

Campbell-Kelly, Martin, 'The Railway Clearing House and Victorian Data Processing', in Lisa Bud-Frierman (ed.), Information Acumen: The Understanding and Use of Knowledge in Modern Business (London: Routledge, 1994), 51-74.

'Data Processing and Technological Change: The Post Office Savings Bank, 1861-1930', Technology and Culture 39/1 (1998), 1-32.

'Information Technology and Organisational Change in the British Census, 1801-1911', in JoAnne Yates and John Van Maanen (eds.), Information Technology and Organizational Transformation: History, Rhetoric, and Practice (London: Sage, 2001), 35-58.

Cane, Colonel Hubert du, (trans.), The War in South Africa: the Advance to Pretoria after Paardeberg, the Upper Tugela Campaign, etc. Prepared in the Historical Section of the Great General Staff, Berlin (London: John Murray, 1906).

Carter, General Sir Nicholas, 'Dynamic Security Threats and the British Army' (Speech Given at the Royal United Services Institute, 22 January 2018), < https://www.gov.uk/government/speeches/dynamic-security-threats-and-the-britisharmy-chief-of-the-general-staff-general-sir-nicholas-carter-kcb-cbe-dso-adc-gen > .

Cassis, Youssef, Big Business: The European Experience in the Twentieth Century (Oxford: Oxford UP, 1997).

Charteris, Brigadier-General John, At GHQ (London: Cassell, 1931).

CIX, 'Letters to an Adjutant', Army Quarterly, 8/1-2 (1924), 31-44, 274-85.

Collins, Jeffrey, and Andrew Futter (eds.), Reassessing the Revolution in Military Affairs:

Transformation, Evolution and Lessons Learnt (London: Palgrave Macmillan, 2015).

Cutlack, F.M., The Australian Flying Corps in the Western and Eastern Theatres of War 1914-1918 (Sydney: Halstead Press, 1923).

Dandeker, Christopher, Surveillance, Power and Modernity (Cambridge: Polity Press, 1994).

Edgerton, David, Science, Technology and the British Industrial 'Decline', 1870-1970 (Cambridge: Cambridge UP, 1996).

Edmonds, J.E., Military Operations, France and Belgium, 1916, Vol. 1 (London: HMSO, 1932).

Military Operations, France and Belgium, 1917, Vol. 2 (London: HMSO, 1948).

Evans, Major Paul W., 'Strategic Signal Communication: A Study of Signal Communication as Applied to Large Field Forces, Based Upon the Operations of the German Signal Corps During the March on Paris in 1914', Signal Corps Bulletin 82 (1935), 24-58.

Farrell, Theo, 'The Dynamics of British Military Transformation', International Affairs 84/4 (2008), 777-807.

Farrell, Theo, Sten Rynning and Terry Terriff, Transforming Military Power Since the Cold War: Britain, France, and the United States, 1991-2012 (Cambridge: Cambridge UP, 2013).

Foley, Robert T., 'A Case Study in Horizontal Military Innovation: The German Army, 1916-1918', Journal of Strategic Studies 35/6 (2012), 799-827.

'Dumb Donkeys or Cunning Foxes? Learning in the British and German Armies during the Great War', International Affairs 90/2 (2014), 279-98. 
Fox, Aimée, Learning to Fight: Military Innovation and Change in the British Army, 19141918 (Cambridge: Cambridge UP, 2018).

Fraser-Tytler, Neil, Field Guns in France (London: Hutchinson, 1922).

French, David, The British Way in Warfare, 1688-2000 (London: Unwin Hyman, 1990).

French, David, and Brian Holden Reid (eds.), The British General Staff: Reform and Innovation, 1890-1939 (London: Routledge, 2002).

Gardner, Nikolas, Trial by Fire: Command and the British Expeditionary Force in 1914 (Westport, CT.: Praeger, 2003).

General Staff, War Office, Staff Manual (War) (London: General Staff, War Office, 1912).

Field Service Regulations Part I: Operations (1909) (Reprinted, with Amendments, October 1914) (London: General Staff, War Office, 1914).

Field Service Regulations Part II: Organization and Administration (1909) (Reprinted, with Amendments, October 1914) (London: General Staff, War Office, 1914).

Field Service Regulations, Vol. II. Operations (London: HMSO, 1935).

Manual of Army Signal Service - War (Provisional) (London: HMSO, 1914).

Godfrey, Simon, British Army Communications in the Second World War: Lifting the Fog of Battle (London: Bloomsbury, 2013).

Goldman, Emily O., (ed.), Information and Revolutions in Military Affairs (London: Routledge, 2005).

Graham, Dominick and Shelford Bidwell, Coalitions, Politicians and Generals: Some Aspects of Command in Two World Wars (London: Brassey's, 1993).

Gray, Colin S., Strategy for Chaos: Revolutions in Military Affairs and the Evidence of History (London: Routledge, 2004).

Griffith, Paddy, Battle Tactics of the Western Front: The British Army's Art of Attack 191618 (London: Yale UP, 1994).

“GSO" [Frank Fox], GHQ (Montreuil-sur-Mer) (London: Philip Allan, 1920).

Gwilliam, Lieutenant W.J., 'A Signal Master on Active Service'. Post Office Electrical Engineers' Journal, 8 (1915-16), 262-3.

Hall, Brian N., Communications and British Operations on the Western Front, 1914-1918 (Cambridge: Cambridge UP, 2017).

Hanson, Neil, with Tom Priestley (eds.), Priestley's Wars (Ilkley: Great Northern Books, 2008).

Harington, Charles, Plumer of Messines (London: John Murray, 1935).

Harris, J.P., Douglas Haig and the First World War (Cambridge: Cambridge UP, 2008).

Harris. J.P., with Niall Barr, Amiens to the Armistice: The BEF in the One Hundred Days' Campaign, 8 August-11 November 1918 (London: Brassey's, 1998).

Harris, Paul, The Men Who Planned the War: A Study of the Staff of the British Army on the Western Front, 1914-1918 (London: Ashgate, 2016).

Higgs, Edward, The Information State in England (London: Palgrave, 2004).

Hildebrand, Brigadier-General A.B.R., 'Second Army Signals, 1914: From the Personal Diary of Brigadier-General A.B.R. Hildebrand', Royal Signals Quarterly Journal 6/21 (1938), 129-41.

Hinton, Matthew (ed.), Introducing Information Management: the Business Approach (Oxford: Butterworth-Heinemann, 2005).

Hogan, Jr., David W., A Command Post at War: First Army Headquarters in Europe, 19431945 (Washington D.C.: Center of Military History, United States Army, 2000). 
Inglefield, Captain V.E., The History of the Twentieth (Light) Division (London: Nisbet, 1921).

Jones, H.A., The War in the Air: Being the Story of the Part Played in the Great War by the Royal Air Force, Vol. 6 (Oxford: Clarendon Press, 1928).

Journal of Strategic Studies 33/4 (2010), Special Issue: The Information Technology Revolution in Military Affairs.

Joyce, Patrick, The State of Freedom: A Social History of the British State since 1800 (Cambridge: Cambridge UP, 2013).

Marble, Sanders, British Artillery on the Western Front in the First World War (London: Routledge, 2013).

McChrystal, General Stanley, My Share of the Task: A Memoir (New York: Portfolio/Penguin, 2014).

McNaughton, Brigadier-General A.G.L., 'Counter Battery Work', Canadian Defence Quarterly, 3/4 (1926), 380-91.

Micklam, Lieutenant G.V., 'The Personal Card Index, or Moderated Methodism', Royal Engineers Journal, 43 (1929), 636-7.

Mitchinson, K.W., The Territorial Force at War, 1914-16 (London: Palgrave Macmillan, 2014).

Musgrave, Captain H., 'The Army System of Correspondence', Royal Engineers Journal 2/1 (1905), 47-51.

Nalder, Major-General R.F.H., The Royal Corps of Signals: A History of its Antecedents and Development, 1800-1955 (London: Royal Signals Institution, 1958).

Nicholson, Colonel W.N., Behind the Lines: An Account of Administrative Staff Work in the British Army 1914-1918 (London: Strong Oak Press, 1989).

Norberg, Arthur L., 'High Technology Calculation in the Early $20^{\text {th }}$ Century: Punched Card Machinery in Business and Government', Technology and Culture 31/4 (1990), 753 79.

Orbell, John, 'The Development of Office Technology', in Alison Turton (ed.), Managing Business Archives (London: Butterworth-Heinrmann, 1991), 60-83.

Palazzo, Albert, 'The British Army's Counter-Battery Staff Office and Control of the Enemy in World War 1', Journal of Military History, 63/1 (1999), 55-74.

Passingham, Ian, Pillars of Fire: the Battle of Messines Ridge, June 1917 (Stroud: Sutton, 1998).

Perry, Nicholas (ed.), Major-General Oliver Nugent and the Ulster Division 1915-1918 (Stroud: Sutton, 2007).

Philpott, William, 'Military History a Century after the Great War', Revue Française de Civilisation Britannique [Online] 20/1 (2015), 2-3, < https://rfcb.revues.org/288 >.

Priestley, J.B., Margin Released: A Writer's Reminiscences and Reflections (London: Mercury Books, 1962).

Priestley, R.E., Work of the Royal Engineers in the European War, 1914-19: The Signal Service (France) (first published 1921; new ed., Uckfield: The Naval and Military Press Ltd., 2006).

Prior, Robin and Trevor Wilson, Command on the Western Front: The Military Career of Sir Henry Rawlinson, 1914-1918 (Oxford: Blackwell, 1992).

Raines, Rebecca Robbins, Getting the Message Through: A Branch History of the US Army Signal Corps (Washington, D.C.: Centre of Military History, 1999). 
Rawling, Bill, 'Communications in the Canadian Corps, 1915-1918: Wartime Technological Progress Revisited', Canadian Military History 3/2 (1994), 6-21.

Robbins, Simon, British Generalship on the Western Front 1914-18: Defeat into Victory (London: Frank Cass, 2005).

Ryan, Sean, 'Finding the Right Answer: Adapting Military Intelligence to the Information Age', RUSI Journal 160/4 (2015), 50-8.

Scott, Peter T. (ed.), 'The View from GHQ: The Second Part of the War Diary of General Sir Charles Deedes', Stand To! Journal of the Western Front Association 11 (1984), 6-17.

Sheffield, Gary and John Bourne (eds.), Douglas Haig War Diaries and Letters 1914-1918 (London: Phoenix, 2006).

Sheffield, Gary, 'Doctrine and Command in the British Army: An Historical Overview', E-2, in Army Doctrine Publication (ADP). Operations (2010), < https://www.gov.uk/government/uploads/system/uploads/attachment_data/file/33695 /ADPOperationsDec10.pdf >.

Simkins, Peter, Kitchener's Army: The Raising of the New Armies 1914-1916 (Manchester: Manchester UP, 1988).

Speight, Captain A., 'G.H.Q. Signal Office, France', Post Office Electrical Engineers' Journal 13 (1920-21), 52-5.

Spiel, Brad, 'Less is More: The Enabled Combat Brigade Headquarters' (5 January 2018), < https://groundedcuriosity.com/less-is-more-the-enabled-combat-brigadeheadquarters/ $>$.

Spiers, Edward, The Late Victorian Army 1868-1902 (Manchester: Manchester UP, 1992).

Storr, Jim, The Human Face of War (London: Continuum, 2009).

Terraine, John (ed.), General Jack's Diary: War on the Western Front 1914-1918 (London: Cassell, 2001).

Thompson, Bill (ed.), General Sir Thomas Morland: War Diaries \& Letters, 1914-1918 (Kibworth Beauchamp: Matador, 2015).

Todman, Dan, 'The Grand Lamasery Revisited: General Headquarters on the Western Front, 1914-1918', in Gary Sheffield and Dan Todman (eds.), Command and Control on the Western Front: The British Army's Experience 1914-18 (Staplehurst: Spellmount, 2004), 39-70.

UK Ministry of Defence, JCN 2/12, Future Land Operating Concept (May 2012).

JDP 6-00 (Third Edition), Communications and Information Systems Support to Joint Operations (January 2008).

'Morpheus Programme: Next Generation Tactical Communication Information Systems for Defence', last updated 18 April 2018, <https://www.gov.uk/guidance/morpheusproject-next-generation-tactical-communication-information-systems-for-defence>.

US Department of Defence, Joint Publication 6-0, Joint Communications System (June 2015), < http://www.dtic.mil/doctrine/new_pubs/jp6_0.pdf >.

US War Department, Field Service Regulations, United States Army, 1923 (Washington D.C.: Government Printing Office, 1924).

van Creveld, Martin, Technology and War: From 2000 B.C. to the Present (New York: Free Press, 1989).

War Office, Statistics of the Military Effort of the British Empire, 1914-1920 (London: HMSO, 1922). 
Yates, JoAnne, Control through Communication: The Rise of System in American Management (Baltimore: John Hopkins UP, 1993).

'Evolving Information Use in Firms, 1850-1920: Ideology and Information Techniques and Technologies', in Lisa Bud-Frierman (ed.), Information Acumen: The Understanding and Use of Knowledge in Modern Business (London: Routledge, 1994), 26-50. 